\title{
Nitrogen and biomass dynamics following brush control in the cross timbers
}

\author{
D.L. GAY, D.M. ENGLE, E.R. ALLEN, AND J.F. STRITZKE
}

Authors are agriculturist, professor, assistant professor, and professor, respectively, Agronomy Department, Oklahoma State University, Stillwater, Okla. 74078 .

Abstract

Converting marginal hardwood forest to grassland has the potential of increasing economic output with livestock grazing. Nitrogen (N) management during conversion needs to be evaluated to minimize possible adverse effects on the environment. This study was conducted to determine temporal changes in quantities of $\mathrm{N}$ and biomass within ecosystem compartments after herbicide application in a mature post oak (Quercus stellata Wangenh.)blackjack oak (Quercus marilandica Muenchh.) forest. The 4 treatments evaluated included; 1) no brush kill with no grass overseeding, 2) brush kill with no grass overseeding, 3) brush kill with cool-season grass overseeding, ' $\mathrm{K}-31$ ' tall fescue (Festuca arundinacea Schreb.), and 4) brush kill with warm-season grass overseeding, 'Plains' Old World bluestem [Bothriochloa ischaemum var. ischaemum (L.) Keng.]. Excellent brush kill was accomplished with $2.2 \mathrm{~kg}$ a.i. $\mathrm{ha}^{-1}$ tebuthiuron $(N-[5-(1,1-$ dimethylethyl)-1,3,4-thiadiazol-2-yl]- $N, N^{\prime}$-dimethylurea) applied in spring 1993. Total $\mathbf{N}$ was measured during a 21 -month period (June 1993 to February 1995), in 15- $\times 25-m$ plots, within 8 compartments; soil (0 to $60 \mathrm{~cm}$ ), roots $(0$ to $60 \mathrm{~cm})$, litter, top growth of herbaceous plants, woody plants $<2.5 \mathrm{~cm}$ in diameter, and leaves, branches, and boles from trees $>2.5 \mathrm{~cm}$ in diameter. Stored $\mathbf{N}$ in tall fescue forage was 6 to 7 times greater than in Old World bluestem or native vegetation by June 1994 and was 2 times greater in October 1994 and February 1995. Above-ground biomass of tall fescue and Old World bluestem was not different in October 1994 or February 1995, but both were greater than native vegetation. Litter biomass and total $\mathbf{N}$ in litter decreased, especially in the tall fescue overseeding treatment. Total $\mathbf{N}$ in the soil for all treatments averaged $5,100 \mathrm{~kg} \mathrm{ha}^{-1}$ and fluctuations were not detectable among treatments. Total $\mathbf{N}$ changes in other compartments were not observable or were minimal. Brush kill and overseeding with grass had little influence on total $N$ stored within the ecosystem for 21 months after treatment. $\mathbf{N}$ was redistributed to the herbaceous biomass compartment and away from the litter compartment after herbicide application, regardless of the overseeding treatment applied.

Key Words: post oak-blackjack oak, nitrogen cycling, nutrient budget, tebuthiuron.

This research was supported by the Oklahoma State University Center for Wate Research and the Oklahoma Agricultural Experiment Station through project S2044 and is approved for publication by the Director of the Oklahoma Agricultural Experiment Station.

Manuscript accepted 22 March 1996.
Resúmen

El transformar un bosque marginal a pastizal inducido posee el potencial de incrementar el rendimiento económico por medio del apacentamiento de ganado. El comportamiento del nitrógeno (N) durante dicha transformación necesita ser evaluado para minimizar los posibles efectos adversos. El presente estudio fue llevado a cabo para determinar cambios temporales en la cantidad de $\mathbf{N}$ y biomasa dentro del ecosistema, después de la aplicación de herbicida (Tebuthiuron) en un bosque de Quercus marilandica. Los 4 tratamientos evaluados incluyeron: 1) Testigo (sin hericida ni siembra), 2). Herbicida sin siembra de pastos, 3) Herbicida más siembra de festuca K-31 (Festuca arundinacea), y 4). Herbicida más siembra se pastos de tallo azul (Bothriochloa ischaemum). Se logró una mortandad excelente con la aplicación de 2.2 kilogramos de i.a/ha de tebuthiuron aplicado en la primavera de 1993. El $\mathbf{N}$ total fue medido durante un periodo de 21 meses (Junio 1993 a Febrero de 1995) en lotes de $15 \times 25 \mathrm{~m}$, dentro de 8 compartimientos: suelo $(0$ a $60 \mathrm{~cm}$.), raices $(0$ a $60 \mathrm{~cm}$.), mantillo orgánico, crecimiento aereo de plantas herbaceas, plantas leñosas de más de $2.5 \mathrm{~cm}$. de diametro y en hojas, ramas y copas de arboles menores de $2.5 \mathrm{~cm}$. de diametro. El $\mathrm{N}$ almacenado en la siembra de festuca alta fue de 6 a 7 veces mayor que en el de pasto tallo azul o en la vegetacion nativa (testigo) en Junio de 1994 y fue 2 veces mayor en Octubre de 1994 y Febrero de 1995. La biomasa aerea de festuca alta y de pasto tallo azul no fue diferente en Octubre de 1994 ni en Febrero de 1995, pero ambos fue superior a la de la vegetacion nativa. La biomasa del mantillo orgánico y el total de $\mathbf{N}$ en el mantillo, disminuyeron especialmente en el tratamiento de siembra con festuca alta. El total de $\mathrm{N}$ en el suelo para todos los tratamientos promedio 5,100 $\mathrm{kg} / \mathrm{ha}$. $\mathrm{y}$ no se detectaron fluctuaciones entre tratamientos. Los cambios totales de $\mathrm{N}$ en otros compartimientos fueron minimos o no observables. La mortandad de arbustivas y la siembra con pastos tuvieron poca influencia sobre el $\mathbf{N}$ total almacenado dentro del ecosistema durante 21 meses despues del tratamiento. El $\mathbf{N}$ fue redistribuido al compartimiento de la biomasa herbacea despues de la aplicacion del herbicida, sin importar el tratamiento de siembra de pastos.

Oklahoma, Texas, and Kansas contain more than 4 million hectares of the cross timbers vegetation type (SCS 1981, Engle 1994). Much of this land has little economic value other than recreational use. Livestock production on these areas is marginal since lack of proper management (i.e., prescribed fire) in the past has reduced thousands of hectares to unmerchantable hardwoods 
(Byrd et al. 1984). Herbicide treatments can improve use and production from this land (Elwell and Cox 1950, Elwell 1968, Elwell et al. 1970, Scifres et al. 1981, McCollum et al. 1987, Scifres et al. 1987, Smith et al. 1987, Smith 1988, Engle et al. 1991, Stritzke et al. 1991), but such severe disturbances may also have negative environmental impacts.

The fate of $\mathrm{N}$ within the ecosystem after disturbance is an environmental concern that has been studied in a variety of forests and shrublands (Likens et al. 1970, Hibbert et al. 1974, Knight et al. 1983, Lloyd-Reilley et al. 1984). When disturbances such as clear-cutting and herbicide treatment occur in forests, large amounts of organic matter can be mineralized resulting in an abundance of available N (Vitousek 1981). Significant N losses through leaching and runoff are typical when plant uptake is temporarily reduced well below the available source of nutrients (Vitousek and Melillo 1979). Negative environmental consequences of $\mathrm{N}$ loss may include a decline in site fertility and productivity.

At the Cross Timbers Experimental Range near Stillwater, Okla., Stritzke et al. (1991) evaluated the response of overstory woody species and Engle et al. (1991) determined the response of understory herbaceous vegetation during secondary autogenic succession after application of herbicides and fire. In the closed overstory of these mature post oak-blackjack oak forests, herbaceous plants were sparse and understory herbage production did not peak until 2 years after herbicide treatment (Engle et al. 1991). A lag time resulted between expected $N$ release and available vegetation for $\mathrm{N}$ uptake. Herbage production peaked at 4,800 $\mathrm{kg} \mathrm{ha}^{-1}$, but by 10 years post treatment, total herbaceous production had dropped to as much as half of the maximum (Unpublished data, Engle et al., Bernardo et al. 1992). Similar herbage production response has been noticed in other studies (Davis 1967, Klimo and Kulhavy 1994). It is possible that loss of $\mathrm{N}$ from the ecosystem was partially responsible for the reduced level of production, although no research has been done to date on the fate of nitrogen in the cross timbers following brush control. If indeed $\mathrm{N}$ is lost after brush control, it is also possible that capturing the mineralized $\mathrm{N}$ in herbaceous material will result in a more sustainable forage production system. The objective of this study was to determine effects of brush kill and grass establishment by overseeding on the temporal variation in $\mathrm{N}$ storage within ecosystem compartments of the cross timbers.

\section{Materials and Methods}

\section{Study Area}

This study was conducted on the Oklahoma State University Research Range, located approximately $11 \mathrm{~km}$ southwest of Stillwater, Okla. The vegetation of the area is dominated by post oak (Quercus stellata Wangenh.) and blackjack oak (Quercus marilandica Muenchh.). The site is an upland forest on a sandy savannah range site. We established study plots on nearly level topography of Stephenville sandy loam soils (fine-loamy, siliceous, thermic Ultic Haplustalfs). Soils in the series have an average depth of $60 \mathrm{~cm}$, are well drained, and are moderately permeable. Annual precipitation in the area averages $830 \mathrm{~mm}$, falling mostly from April to October. Mean annual temperature is $15.5^{\circ} \mathrm{C}$, with the mean in January of $2.3^{\circ} \mathrm{C}$, and the mean in July of $27.6^{\circ} \mathrm{C}$ (Myers 1982).

\section{Treatments and Design}

Sixteen plots, $(15 \times 25 \mathrm{~m})$, with 4 replications of 4 treatments were arranged in a completely randomized design. The 4 treatments evaluated included; 1) no brush kill with no grass overseeding (untreated control), 2) brush kill with no grass overseeding, 3) brush kill with cool-season grass overseeding, and 4) brush kill with warm-season grass overseeding. The brush kill with no grass overseeding treatment, which revegetated by secondary autogenic succession, consisted of mostly annual forbs. The overseeded cool-season grass was 'K-31' tall fescue (Festuca arundinacea Schreb.). 'Plains' Old World bluestem [Bothriochloa ischaemum var. ischaemum (L.) Keng.] was the warm-season grass overseeded. Brush kill was achieved with tebuthiuron (N-[5-(1,1dimethylethyl)-1,3,4-thiadiazol-2-yl]- $N, N^{\prime}$-dimethylurea), which was applied to 8 of the plots in March 1993 and to 4 of the plots in May 1993, at a rate of $2.2 \mathrm{~kg}$ a.i. $\mathrm{ha}^{-1}$. The tebuthiuron effect on overstory oaks resulted in excellent control with results similar to those reported by Stritzke et al. (1991). To prepare a seedbed, leaf litter in the 12 herbicide-treated plots was removed by burning on 30 September 1993. Eight plots were immediately overseeded (4 with tall fescue at $15 \mathrm{~kg} \mathrm{PLS} \mathrm{ha}^{-1}$ and 4 with Old World bluestem at $6 \mathrm{~kg} \mathrm{PLS} \mathrm{ha}^{-1}$ ) and 4 were left unseeded. The remaining 4 served as controls and were not treated with herbicide, burned, or overseeded. Tall fescue emerged in the Fall of 1993 and established $100 \%$ ground cover by April 1994. Old World bluestem emerged in the Spring of 1994 and established 100\% ground cover by August 1994.

\section{Field Sampling}

Plots were randomly subdivided into 6 sections to match 6 sampling dates over a 21 -month period (June 1993 through February 1995). All compartments were randomly sampled in a different section at each date to avoid disturbance before sample collection. Sampling dates corresponded to either expected pulses of plant $\mathrm{N}$ uptake or mineralized $\mathrm{N}$ in the soil. We sampled in June 1993 to measure base $\mathrm{N}$ levels before tebuthiuron treatment was effective. November 1993 sampling coincided with expected maximum accumulation of mineralized $\mathrm{N}$ in biomass of original vegetation because growth of both cool-season and warm-season vegetation is insignificant by then. We sampled in January 1994 to correspond with maximum accumulation of mineralized $\mathrm{N}$ in the soil, because mineralization by this time is minimal, tall fescue would not be actively growing, and old World bluestem would not yet have germinated. The June 1994 sampling represented reduced $\mathrm{N}$ uptakc and near maximum accumulation of mineralized $\mathrm{N}$ by tall fescue, corresponding to time of seed production and reduced growth in tall fescue. The October 1994 sampling, after the first killing frost, represented maximum accumulation of mineralized $\mathrm{N}$ by Old World bluestem.

Finally, sampling in February 1995, we expected maximum mineralized $\mathrm{N}$ in the soil before uptake by tall fescue and Old World bluestem began in the second growing season. Biomass and $\mathrm{N}$ concentrations were determined in samples from 5 compartments: soil, roots, litter, herbaceous plants, and woody plants with a diameter at breast height $(\mathrm{dbh})$ of $<2.5 \mathrm{~cm}$. We collected samples for $\mathrm{N}$ concentrations in 3 additional compartments: leaves, branches, and boles from trees with a dbh $>2.5 \mathrm{~cm}$. Biomass in compartments of trees with a dbh $>2.5 \mathrm{~cm}$ was estimated from values of Johnson and Risser (1974). 
Soils were sampled and composited from 5 random locations per plot. Samples were taken with a $2.5-\mathrm{cm}$ diameter corer at 4 depth increments (0 to 15,15 to 30,30 to 45 , and 45 to $60 \mathrm{~cm}$ ). Root biomass was sampled in 3 root cores per plot by driving a $6.5 \mathrm{~cm}$ diameter corer into the ground and extracting cores in the same depth increments as soil. Litter samples were collected to mineral soil within three $0.25-\mathrm{m}^{2}$ circular quadrats per plot. Herbaceous material and woody $(<2.5 \mathrm{~cm} \mathrm{dbh})$ material were sampled within three $1.0-\mathrm{m}^{2}$ circular quadrats per plot. Twenty tree leaves per plot were collected randomly on those dates when leaves were alive and present in the canopy. Ten branches $(<1.25$ $\mathrm{cm}$ in diameter) per plot were randomly collected, excluding current years growth. Two bole samples per plot were randomly collected with a 5.15-mm increment borer.

\section{Laboratory Procedures}

Soil samples were dried at $90^{\circ} \mathrm{C}$ in a forced air drying oven and ground in a hammer mill to pass a $2.0-\mathrm{mm}$ mesh screen. Biomass samples were dried at $65^{\circ} \mathrm{C}$. Litter, herbaceous, and woody samples were weighed, composited, and subsampled by quartering before grinding. Roots were separated from root core samples by washing the composited samples with water through 20-mesh and 32-mesh screens simultaneously to recover root fragments. All biomass samples were ground in Wiley and Udy mills consecutively to pass $4.0-\mathrm{mm}$ and $0.5-\mathrm{mm}$ mesh screens, respectively. Both soil and biomass samples were analyzed in the LECO N analyzer, model FP 428, by dry combustion for total $\mathrm{N}$ as described by Bremner and Mulvaney (1982). Total compartment $\mathrm{N}$ was calculated as the product of the compartment $\mathrm{N}$ concentration and mass. Total $\mathrm{N}$ value for the ecosystem in each treatment over time was calculated as the sum of all $\mathrm{N}$ in all compartments. Soil total $\mathrm{N}$ values by depth were adjusted for differences in bulk density by using the average weight of 60 core samples per 15 $\mathrm{cm}$ soil depth increment taken from the study area in February 1995. Nitrogen values were converted to $\mathrm{kg} \mathrm{ha}^{-1}$. We present total soil $\mathrm{N}$ for the beginning June 1993 sampling date and the ending February 1995 sampling dates because laboratory analysis was done on these samples initially. No treatment differences were detected, so we did not analyze the samples from other dates.

\section{Statistical Analysis}

Statistical analysis was performed with a split-plot-in-time arrangement of treatments in an analysis of variance. Treatments were main units and dates were subunits. Differences between treatments were detected with the following single-degree-of- freedom contrasts: no brush kill vs. brush kill, brush kill with overseeding vs. brush kill with no overseeding, and brush kill with cool-season grass overseeding vs. brush kill with warm-season grass overseeding. A 2-tailed t-test was used to compare means in all compartments and contrasts except for the herbaceous compartment. We expected an increase in total $\mathrm{N}$ in the herbaceous material in June 1994 , so a 1-tailed t-test was used to compare treatment means for this date. However, we had no basis for anticipating whether tall fescue or Old World bluestem would have accumulated greater total $\mathrm{N}$ in October 1994 or February 1995, so we used a 2 -tailed t-test to contrast the overseeding treatments at those dates.

\section{Results and Discussion}

\section{Below-ground Nitrogen and Biomass}

Total soil $\mathrm{N}\left(0\right.$ to $60 \mathrm{~cm}$ ) in June 1993 was about $5,000 \mathrm{~kg} \mathrm{ha}^{-1}$ (Table 1). Johnson and Risser (1974) reported $9,591 \mathrm{~kg} \mathrm{ha}^{-1}$ total soil $\mathrm{N}$ to an average soil depth of $300 \mathrm{~cm}$ in a similar post oakblackjack oak area. Our values appear high but are likely more accurate for the 0 - to $60-\mathrm{cm}$ soil layer than those of Johnson and Risser because we measured total $\mathrm{N}$ in 4 succeeding soil layers. Johnson and Risser estimated total $\mathrm{N}$ for lower soil depths based on total $\mathrm{N}$ in the 0 - to 15 - and $30-$ to $45-\mathrm{cm}$ soil layers only. Soil organic matter and total $\mathrm{N}$ decrease with soil depth and would be difficult to estimate at $300 \mathrm{~cm}$ from samples at $30 \mathrm{~cm}$. Sears et al. (1986) reported total soil $\mathrm{N}$ values ranging from 1,346 to 2,153 $\mathrm{kg} \mathrm{ha}^{-1}(0$ to $60 \mathrm{~cm})$ in the sand shinnery oak (Quercus havardii Rydb.) community of West Texas, which are half those we reported. The primary soil in the sand shinnery oak community of West Texas is a fine sand 40 to $70 \mathrm{~cm}$ deep. Less organic matter and total $\mathrm{N}$ would be expected in the sandy, more arid soils of West Texas.

No differences were detected in total soil $\mathrm{N}$ among treatments at the June 1993 or February 1995 sampling (Table 1). Either the 21-month sampling period was too brief for changes in total soil $\mathrm{N}$ to be detected in response to woody material decomposition, or total $\mathrm{N}$ was not affected by brush kill. Differences might have been detected in the top $5 \mathrm{~cm}$ of soil if sampling depth increments had been smaller. Soil $\mathrm{NO}_{3}-\mathrm{N}$, however, in all the brush kill plots compared to the untreated plots rose from $<3 \mathrm{~kg} \mathrm{ha}^{-1}$ to $>60 \mathrm{~kg}$ $\mathrm{ha}^{-1}$ (Gay et al. 1996), but at maximum levels this represented only about $1.0 \%$ of the total $\mathrm{N}$ in the soil.

Table 1. Total $N$ in soil by treatment and depth in a post oak-blackjack oak community in the cross timbers of north central Oklahoma following herbicide application.

\begin{tabular}{|c|c|c|c|c|c|c|c|c|}
\hline \multirow[b]{2}{*}{ Depth $(\mathrm{cm})$} & \multicolumn{4}{|c|}{ June 1993} & \multicolumn{4}{|c|}{ February 1995} \\
\hline & Control $^{1}$ & No seed & Fescue & OWB & Control & No seed & Fescue & OWB \\
\hline & $\ldots$ & $\ldots \ldots$ & $\ldots \ldots$ & $\cdots(k$ & $\ldots \ldots$ & $\ldots \ldots$ & $\ldots \ldots$ & $\ldots$ \\
\hline 0 to 15 & $1,920^{2}$ & 1,980 & 1,710 & 1,810 & 1,860 & 1,810 & 1,710 & 1,400 \\
\hline 15 to 30 & 590 & 990 & 870 & 700 & 930 & 1,010 & 1,060 & 850 \\
\hline 30 to 45 & 930 & 1,220 & 1,230 & 1,170 & 1,310 & 1,390 & 1,350 & 1,220 \\
\hline 45 to 60 & 1,000 & 1,090 & 990 & 870 & 1,350 & 1,400 & 1,380 & 1,160 \\
\hline 0 to 60 & 4,430 & 5,280 & 4,800 & 4,540 & 5,450 & 5,610 & 5,510 & 4,620 \\
\hline
\end{tabular}

Treatments are: control = no brush kill with no overseeding, no seed = brush kill with no overseeding, fescue = brush kill with tall fescue overseeding, OWB = brush kill with Old World bluestem overseeding

2 No differences $P>0.05$. 
Table 2. Total $\mathrm{N}$ and biomass in roots ( $<2.5 \mathrm{~cm}$ diameter) by date and treatment in a post oak-blackjack oak community in the cross timbers of north central Oklahoma following herbicide application.

\begin{tabular}{|c|c|c|c|c|c|c|c|c|c|c|c|c|}
\hline \multirow{2}{*}{$\begin{array}{l}\text { Soil depth and } \\
\text { treatment }\end{array}$} & \multicolumn{2}{|c|}{ Jun 1993} & \multicolumn{2}{|c|}{ Nov 1993} & \multicolumn{2}{|c|}{$\operatorname{Jan} 1994$} & \multicolumn{2}{|c|}{ Jun 1994} & \multicolumn{2}{|c|}{ Oct 1994} & \multicolumn{2}{|c|}{ Feb 1995} \\
\hline & Total N & Biomass & Total N & Biomass & Total $\mathbf{N}$ & Biomass & Total N & Biomass & Total N & Biomass & Total N & Biomass \\
\hline$(0$ to $15 \mathrm{~cm})$ & -- & ---- & $-\cdots$ & $\cdots-\cdots$ & $\cdots$ & $\ldots-(\mathrm{kg} \mathrm{h}$ & $-1)-\ldots$ & ------ & ---- & ----- & ----- & ---- \\
\hline Control & 31 & 4,000 & 55 & 6,110 & 37 & 3,890 & 22 & 3,260 & 44 & 7,060 & 22 & 2,450 \\
\hline No seed & 42 & 5,480 & 34 & 3,960 & 31 & 4,470 & 27 & 3,970 & 32 & 4,320 & 24 & 2,600 \\
\hline Fescue & 50 & 6,530 & 26 & 3,030 & 34 & 4,410 & 39 & 4,790 & 42 & 5,020 & 46 & 4,370 \\
\hline OWB & 31 & 4,470 & 40 & 4,763 & 28 & 3,460 & 22 & 2,890 & 24 & 2,810 & 25 & 3,270 \\
\hline \multicolumn{13}{|l|}{ Contrasts $^{2}$} \\
\hline Control vs brush kill &.- & --- & --- & -- & $\cdots$ & --- & --- & --- & -- & --- & $\cdots$ & $\cdots$ \\
\hline No seed vs seed & $\cdots$ & --- & --- & $-\cdots$ & $\cdots$ & -- & --- & $\ldots-$ & --- & --- & --- & --- \\
\hline Fescue vs OWB & $\cdots$ & -- & $\cdots$ & $\cdots$ & -- & -- & $\dagger$ & $\dagger$ & * & $\dagger$ & $\dagger$ & -- \\
\hline \multicolumn{13}{|l|}{$(15 \text { to } 60 \mathrm{~cm})^{3}$} \\
\hline Control & 49 & 9,400 & 85 & 13,680 & 89 & 14,550 & 64 & 12,860 & 71 & 13,270 & 97 & 17,630 \\
\hline No seed & 67 & 10,670 & 109 & 15,970 & 77 & 12,070 & 59 & 8,960 & 47 & 7,800 & 53 & 8,690 \\
\hline Fescue & 118 & 18,470 & 66 & 10,740 & 83 & 13,790 & 80 & 13,930 & 71 & 10,840 & 63 & 11,000 \\
\hline OWB & 74 & 13,540 & 102 & 15,010 & 71 & 11,200 & 47 & 7,520 & 59 & 9,680 & 73 & 12,890 \\
\hline
\end{tabular}

Treatments are: control $=$ no brush kill with no overseeding, no seed $=$ brush kill with no overseeding, fescue $=$ brush kill with tall fescue overseeding, OWB $=$ brush kill with Old World bluestem overseeding.

$2_{\dagger}{ }^{*}$, Significant at the 0.10 , and 0.05 probability levels, respectively. Dashed line represents no difference in contrast.

${ }^{3}$ No significant treatment F-tests for the lower depth increments. These data represent a sum of the lower 3, 15-cm depth increments.

Root biomass differed $(\mathrm{P} \leq 0.10)$ between tall fescue overseeding and Old World bluestem overseeding in June and October of 1994 in the 0- to $15-\mathrm{cm}$ soil layer (Table 2). The smaller root quantity in plots overseeded with Old World bluestem could help explain the lack of $N$ uptake in that treatment (Gay et al. 1996). Total $\mathrm{N}$ stored in root biomass was also lower in the Old World bluestem plots. Our estimate of $18,000 \mathrm{~kg} \mathrm{ha}^{-1}$ in root $(<2.5 \mathrm{~cm})$ biomass to a depth of $60 \mathrm{~cm}$ and $115 \mathrm{~kg} \mathrm{~N} \mathrm{ha}^{-1}$ in roots in June 1993 averaged over all treatments appears lower than the 30,000 $\mathrm{kg} \mathrm{ha}^{-1}$ root biomass $\left(0\right.$ to $60 \mathrm{~cm}$ ) and $169 \mathrm{~kg} \mathrm{~N} \mathrm{ha}^{-1}$ for a similar area reported by Johnson and Risser (1974).

\section{Above-ground Nitrogen and Biomass}

Total $\mathrm{N}$ within the litter compartment was reduced after brush kill by June 1994 (Table 3), but burning in late September 1993 apparently had little influence on litter biomass or total $\mathrm{N}$ because no difference was detected in the control vs. brush kill contrast in November 1993. Lab analysis of leaf litter collected before burning suggested an average of $8,900 \mathrm{~kg}$ biomass ha- ${ }^{-1}$ and $177 \mathrm{~kg} \mathrm{~N}$ $\mathrm{ha}^{-1}$ could have been lost in burning the brush kill plots, assuming all of the $\mathrm{N}$ was volatilized from the leaf litter consumed by fire. This agrees with Van Lear and Kapeluck (1989) who estimated losses of $\mathrm{N}$ ranging from 130 to $170 \mathrm{~kg} \mathrm{ha}^{-1}$ in a burned, mixed pine-hardwood forest. Our burning was done on 30 September 1994 and post-burn litter was not collected until November 1994. The lack of detectable differences could have occurred because leaf fall had not completely occurred in September and leaf fall after that date disguised any burning effects. We may have also overestimated the amount of leaf litter that was actually consumed by fire. The differences in total litter N found in June 1994 were still observed in October 1994 and February 1995 in the brush kill plots, which were burned, compared to the no brush kill plots. By February 1995, the tall fescue overseeding plots had less litter biomass and less total litter $\mathrm{N}$ than plots overseeded with Old World bluestem. The difference may have begun in April 94 when a more mesic micro-climate at the soil surface was created by the overseeded tall fescue, allowing litter decomposition to begin sooner than in the Old World bluestem plots. Ground cover establishment for tall fescue was April 1994 whereas for Old World bluestem it was August 1994.

Herbaceous biomass increased after brush kill both with and without overseeding (Table 4). Both the tall fescue and Old World bluestem overseeding treatments produced $>3,000 \mathrm{~kg} \mathrm{ha}^{-1}$ above-ground biomass the first growing season compared to $1,800 \mathrm{~kg} \mathrm{ha}^{-1}$ in the brush kill with no overseeding. However, there was a difference in total $\mathrm{N}$ stored in tall fescue and total $\mathrm{N}$

Table 3. Total $\mathrm{N}$ and biomass in litter by date and treatment in a post oak-blackjack oak community in the cross timbers of north central Oklahoma following herbicide application.

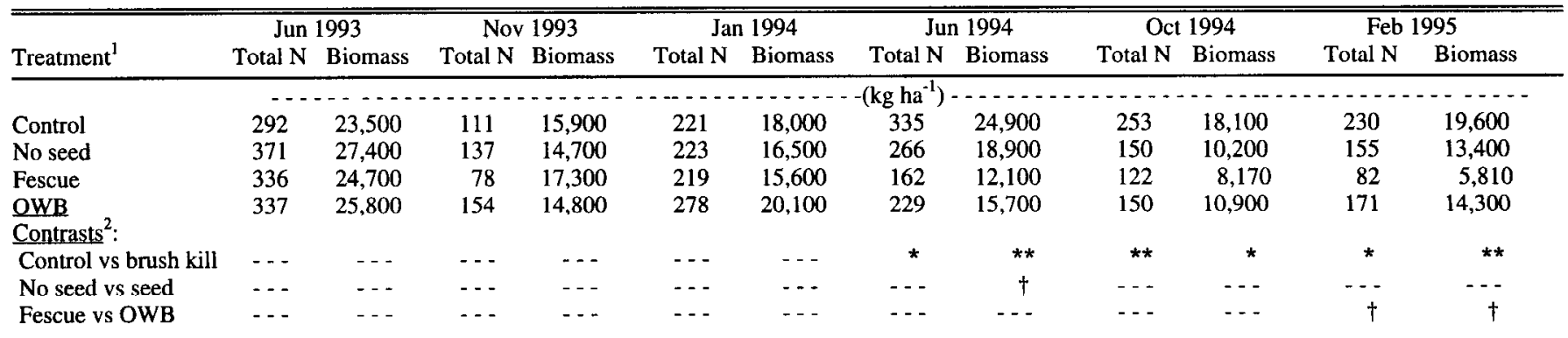

Treatments are: control = no brush kill with no overseeding, no seed = brush kill with no uverseeding, fescue = brush kill with tall fescue overseeding, OwB - brush kill with Old World bluestem overseeding.

$2_{\dagger, *}^{*}{ }^{\star}$, significant at the $0.10,0.05$, and 0.01 probability levels respectively. Dashed line represents no significant difference in contrast. 


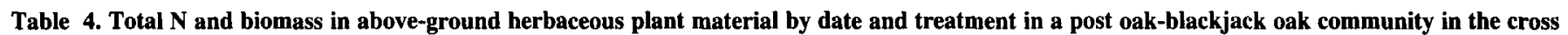
timbers of north central Oklahoma following herbicide application.

\begin{tabular}{|c|c|c|c|c|c|c|c|c|c|c|c|c|}
\hline \multirow{2}{*}{$\begin{array}{l}\text { Soil depth and } \\
\text { treatment }\end{array}$} & \multicolumn{2}{|c|}{ Jun 1993} & \multicolumn{2}{|c|}{ Nov 1993} & \multicolumn{2}{|c|}{ Jan 1994} & \multicolumn{2}{|c|}{ Jun 1994} & \multicolumn{2}{|c|}{ Oct 1994} & \multicolumn{2}{|c|}{ Feb 1995} \\
\hline & Total N & Biomass & Total N & Biomass & Total N & Biomass & Total N & Biomass & Total N & Biomass & Total N & Biomass \\
\hline & $\ldots$ & $-\cdots$ & $\ldots . .$. & $\ldots \ldots$ & $\ldots$ & $-\left(\mathrm{kg} \mathrm{ha}^{-1}\right)$ & $\ldots-\ldots$ & $\ldots \ldots$ & $\ldots$ & $-\ldots$ & $\ldots .$. & $-\ldots-$ \\
\hline Control & 0.1 & 10 & 0.1 & 10 & 0.2 & 20 & 0.4 & 30 & 0.2 & 20 & 0.0 & 0 \\
\hline No seed & 0.1 & 10 & 0.0 & 0 & 0.0 & 0 & 7.4 & 240 & 26.5 & 1,790 & 7.7 & 640 \\
\hline Fescue & 0.0 & 0 & 0.0 & 0 & 0.0 & 0 & 40.6 & 1,760 & 66.3 & 3,480 & 41.8 & 2,600 \\
\hline $\begin{array}{l}\text { OWB } \\
\text { Contrasts }\end{array}$ & 0.1 & 10 & 0.0 & 0 & 0.0 & 0 & 6.3 & 210 & 34.3 & 3,100 & 21.9 & 2,380 \\
\hline Control vs brush kill & $1 \ldots$ & $\ldots$ & $-\ldots$ & -- & $\ldots$ & $\cdots$ & $\star * *$ & $* * *$ & $* * *$ & $* * *$ & $* * *$ & $* * *$ \\
\hline No seed vs seed & -- & --- & -- & $\cdots$ & --- & --- & -- & -- & * & -- & ** & * \\
\hline Fescue vs OWB & $\ldots$ & $\ldots$ & -- & -- & -- & -- & $\star \star *$ & * & * & -- & -- & -- \\
\hline
\end{tabular}

${ }^{1}$ Treatments are: control $=$ no brush kill with no overseeding, no seed $=$ brush kill with no overseeding, fescue $=$ brush kill with tall fescue overseeding, OWB $=$ brush kill with Old World bluestem overseeding.

$2 *, \star *, * * *$ Significant at the $0.05,0.01$, and 0.001 probability levels respectively. Dashed line represents no significant difference in contrast.

stored in Old World bluestem. Whereas untreated plots contained almost no $\mathrm{N}$ in herbaceous biomass, plots with tall fescue overseeding sequestered over $60 \mathrm{~kg} \mathrm{~N}^{-1}$ in above-ground biomass by Octoher 1994, compared to $34 \mathrm{~kg} \mathrm{~N} \mathrm{ha}^{-1}$ in plots overseeded with Old World bluestem. Unseeded brush-kill plots, which revegetated through secondary autogenic succession, stored about half the $\mathrm{N}$ in above-ground biomass as the tall fescue-overseeded plots and about the same as Old World bluestem-overseeded plots. Growth stage when harvested may partially explain the lower concentrations of $\mathrm{N}$ observed in Old World bluestem than in tall fescue. It is also known that 1 characteristic of plants with the $\mathrm{C}_{4}$-photosynthetic pathway (i.e. Old World bluestem) is a more efficient use of $\mathrm{N}$ (Waller and Lewis 1979). This does not explain, however, why Old World bluestem did not produce more biomass than tall fescue if the $\mathrm{N}$ present was more efficiently utilized by Old World bluestem. One likely explanation is that during Old World bluestem seedling establishment in May and June of 1994 , precipitation was half of the long term mean for the area (118 mm vs. $225 \mathrm{~mm}$ ) (Table 5). Soil water within the seedling root zone was limiting plant growth and $\mathrm{N}$ uptake. When rainfall amounts returned to normal, there was insufficient time in the

Table 5. Precipitation summary during experiment and long-term precipitation average at the Oklahoma Agriculture Experiment Station, Stillwater Agronomy Research Station, Stillwater, Okla.

\begin{tabular}{lrrrr}
\hline \hline & \multicolumn{3}{c}{ Year } \\
\cline { 2 - 5 } Month & 1993 & 1994 & 1995 & $1893-1994$ \\
\hline & -19 & 1 & 26 & 29 \\
January & 57 & 54 & 3 & 35 \\
February & 63 & 94 & 119 & 60 \\
March & 61 & 120 & 112 & 86 \\
April & 211 & 72 & & 127 \\
May & 241 & 46 & & 102 \\
June & 87 & 86 & & 74 \\
July & 65 & 91 & & 75 \\
August & 78 & 71 & & 95 \\
September & 119 & 49 & & 73 \\
October & 17 & 134 & & 53 \\
November & 43 & 18 & & 36 \\
December & 27 & 836 & & 843 \\
Total & 1069 & & & \\
\hline
\end{tabular}

growing season for substantial growth of Old World bluestem.

Small ( $<2.5 \mathrm{~cm} \mathrm{dbh}$ ) woody plants were a minor biomass component (Table 6) and had little influence on ecosystem total $\mathrm{N}$ after brush kill. Biomass and total $\mathrm{N}$ in the brush kill treatments were less than in control treatments, but total $\mathrm{N}$ was $<0.1 \%$ of the $\mathrm{N}$ in the entire system and less than $0.4 \%$ of the $\mathrm{N}$ in aboveground and below-ground biomass combined.

We have observed that branches of large trees $(>2.5 \mathrm{~cm} \mathrm{dbh})$ do not begin to fall until 2 years post-herbicide treatment, and tree boles remain standing for 3 to 10 years after treatment. Decomposition is slow because the biomass is suspended and remains relatively dry. Indeed, neither $\mathrm{N}$ concentrations in branches or boles changed over the 21-month period (Table 7). Total N stored in these compartments, obtained by using Johnson and Risser (1974) tree biomass data, did not change either. Biomass reported by Johnson and Risser (1974) was $109,500 \mathrm{~kg}$ $\mathrm{ha}^{-1}$ for tree boles, $64,563 \mathrm{~kg} \mathrm{ha}^{-1}$ for branches, and $4,759 \mathrm{~kg} \mathrm{ha}^{-1}$ for leaves. While biomass of boles and branches did not change over the 21-month period, leaf biomass was reduced the second growing season after herbicide treatment and tree mortality. Minimal leaf production in the 1994 growing season resulted in $110 \mathrm{~kg} \mathrm{~N} \mathrm{ha}^{-1}$ that was not taken up by tree roots.

\section{Summary and Conclusions}

Brush kill and overseeding with grass had little influence on total $\mathrm{N}$ stored within the ecosystem for 21 months after treatment. Although soil $\mathrm{NO}_{3}-\mathrm{N}$ increased following brush kill (Gay et al. in press), total $\mathrm{N}$ within the soil remained unchanged. Total $\mathrm{N}$ in roots did not change except in the $0-$ to $15-\mathrm{cm}$ soil layer. Herbaceous above-ground biomass and total $\mathrm{N}$ increased regardless of the treatment applied. Total $\mathrm{N}$ and biomass decreased within the litter compartment in all the brush-kill treatments. The most evident changes in $\mathrm{N}$ distribution occurred in the brush kill followed by overseeding with tall fescue.

A range of values from beginning and ending sampling dates in this post oak-blackjack forest indicate that of the total $\mathbf{N}$ stored within the ecosystem, 77 to $88 \%$ is stored in the soil, 2 to $3 \%$ in small $(<2.5 \mathrm{~cm})$ roots, 1 to $6 \%$ in litter, 0 to $1 \%$ in herbaceous material, and 8 to $15 \%$ in all woody biomass. Total ecosystem $\mathrm{N}$ 
Table 6. Total $\mathrm{N}$ and biomass in small (<2.5 $\mathrm{cm}$ dbh) woody plants by date and treatment in a post oak-blackjack oak community in the cross timbers of north central Oklahoma following herbicide application.

\begin{tabular}{|c|c|c|c|c|c|c|c|c|c|c|c|c|}
\hline \multirow[b]{2}{*}{ Treatment $^{1}$} & \multicolumn{2}{|c|}{ Jun 1993} & \multicolumn{2}{|c|}{ Nov 1993} & \multicolumn{2}{|c|}{ Jan 1994} & \multicolumn{2}{|c|}{ Jun 1994} & \multicolumn{2}{|c|}{ Oct 1994} & \multicolumn{2}{|c|}{ Feb 1995} \\
\hline & Total N & Biomass & Total N & Biomass & Total N & Biomass & Total N & Biomass & Total N & Biomass & Total N & Biomass \\
\hline \multicolumn{13}{|c|}{ 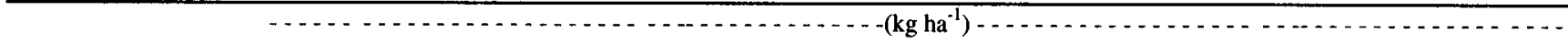 } \\
\hline Control & 4.0 & 348 & 0.3 & 26 & 0.7 & 79 & 4.4 & 424 & 2.4 & 304 & 3.0 & 420 \\
\hline No seed & 2.4 & 218 & 0.4 & 57 & 0.7 & 74 & 1.3 & 65 & 0.4 & 66 & 0.3 & 46 \\
\hline Fescue & 1.9 & 95 & 0.4 & 32 & 0.4 & 45 & 0.4 & 27 & 0.5 & 44 & 0.3 & 26 \\
\hline$\underline{\text { OWB }}$ & 0.8 & 45 & 0.9 & 94 & 0.0 & 2 & 0.2 & 10 & 0.0 & 2 & 0.0 & 3 \\
\hline \multicolumn{13}{|l|}{ Contrasts $^{2}$ : } \\
\hline$\overline{\text { Control vs brush kill }}$ & 1 - - & -- & - & $-\ldots$ & $\ldots$ & $\ldots$ & $\star \star \star$ & ** & ** & ** & $\star \star \star$ & * \\
\hline No seed vs seed & -- & $\ldots$ & $\ldots$ & $\ldots$ & -- & -- & $\ldots$ & -- & $\ldots$ & $\ldots$ & $\ldots$ & -- \\
\hline Fescue vs OWB & $\cdots$ & -- & -- & $\ldots$ & $-\ldots$ & -- & $\ldots$ & $\ldots$ & $\ldots$ & $\ldots$ & -- & -- \\
\hline
\end{tabular}

Treatments are: control = no brush kill with no overseeding, no seed = brush kill with no overseeding, fescue = brush kill with tall fescue overseeding,

OWB = brush kill with Old World bluestem overseeding.

$\star_{\star}, * *, * * *$ Significant at the $0.05,0.01$, and 0.001 probability levels respectively. Dashed line represents no significant difference in contrast.

ranges from 5,500 to $6,600 \mathrm{~kg} \mathrm{ha}^{1}$, of which 770 to $940 \mathrm{~kg} \mathrm{ha}^{-1}$ is stored in above-ground biomass excluding forest floor $\mathrm{N}$. This estimate of $\mathrm{N}$ in above-ground biomass is similar to the $902 \mathrm{~kg}$ $\mathrm{ha}^{-1}$ reported by Johnson and Risser (1974). Others, summarized by Khanna and Ulrich (1991), have reported much lower values of $139 \mathrm{~kg} \mathrm{~N} \mathrm{ha}^{-1}$ in an oak-hickory (Quercus-Carya) forest in Missouri and $470 \mathrm{~kg} \mathrm{~N} \mathrm{ha}^{-1}$ in an oak-hickory forest in Tennessee, with a near equivalent value of $995 \mathrm{~kg} \mathrm{~N} \mathrm{ha}^{-1}$ in an oak-hickory forest in North Carolina. These results indicate the post oakblackjack oak forest of the cross timbers is a nitrogen-rich ecosystem, in a productive temperate climate, with the potential for redistribution of $\mathrm{N}$ to enhance utilization from these marginal forests by grazing and browsing animals. Longer-term studies are needed because decomposition of woody biomass, which was the second largest $\mathrm{N}$ pool in this ecosystem, would ultimately influence redistribution or loss of $\mathrm{N}$.

Table 7. N concentrution by compartment and date for each treatment $(n=4)$ in a post oak-blackjack oak community in the cross timbers of north central Oklahoma following herbicide application.

\begin{tabular}{|c|c|c|c|c|c|c|}
\hline \multirow{2}{*}{$\begin{array}{l}\text { Compartment } \\
\text { and } \\
\text { treatment }^{1}\end{array}$} & \multicolumn{6}{|c|}{ Sampling Date } \\
\hline & Jun 93 & Nov 93 & $\operatorname{Jan} 94$ & Jun 94 & Oct 94 & Feb 95 \\
\hline & -- & -- & $-(\%)$ & $\cdots$ & -1 & --- \\
\hline \multicolumn{7}{|l|}{ Leaves } \\
\hline Control & $1.94^{2}$ & $--^{3}$ & -- & 2.14 & 1.45 & $\ldots$ \\
\hline No seed & 2.32 & -- & -- & --- & -- & $\cdots$ \\
\hline Fescue & 2.35 & -- & $\cdots$ & --- & -- & --- \\
\hline OWB & 2.60 & -- & $--_{-}$ & $\cdots$ & $\ldots$ & -- \\
\hline \multicolumn{7}{|l|}{ Branches } \\
\hline Control & 0.65 & 1 & 0.73 & 0.42 & 0.51 & 0.51 \\
\hline No seed & 0.68 & 1 & 0.69 & 0.48 & 0.55 & 0.53 \\
\hline Fescue & 0.68 & 1 & 0.74 & 0.51 & 0.59 & 0.49 \\
\hline OWB & 0.74 & 1 & 0.76 & 0.53 & 0.49 & 0.58 \\
\hline \multicolumn{7}{|l|}{ Boles } \\
\hline Control & 0.25 & 0.26 & 0.24 & 0.18 & 0.19 & 0.18 \\
\hline No seed & 0.24 & 0.24 & 0.24 & 0.19 & 0.18 & 0.21 \\
\hline Fescue & 0.26 & 0.23 & 0.23 & 0.17 & 0.18 & 0.19 \\
\hline OWB & 0.26 & 0.22 & 0.24 & 0.19 & 0.17 & 0.18 \\
\hline
\end{tabular}

Treatments are: control $=$ no brush kill with no overseeding, no seed $=$ brush kill with no overseeding, fescue $=$ brush kill with tall fescue overseeding, $\mathrm{OWB}=$ brush kill with Old World bluestem overseeding.

${ }^{2}$ No differences $P>0.05$.

${ }^{3}$ Dashed line indicates live leaves were not available in the canopy for sampling. Backslash indicates missing samples.

\section{References}

Bernardo, D.J., D.M. Engle, R.L. Lochmiller, and F.T. McCollum. 1992. Optimal vegetation management under multiple-use objectives in the cross timbers. J. Range Manage. 45:462-469.

Bremner, J.M. and C.S. Mulvaney. 1982. Nitrogen-Total, p. 595-597. In: A.L. Page, R.H. Miller, and D.R. Keeney (eds.), Methods of soil analysis. Part 2-Chemical and microbiological properties. American Society of Agronomy, Inc. Soil Science Society of America, Inc. Madison, Wis.

Byrd, N.A., C.E. Lewis, and H.A. Pearson. 1984. Management of southern pine forest for cattle production. USDA Forest Serv. Gen. Rep. R8-GR4.

Davis, A.M. 1967. Range development through brush control in the Arkansas Ozarks. Arkansas Agr. Exp. Stn. Bull. 726. Fayetteville, Ark.

Elwell, H.M. 1968. Phenoxy herbicides control blackjack and post oak release native grasses. Down to Earth. 24:3-5.

Elwell, H.M. and M.B. Cox. 1950. New methods of brush control for more grass. J. Range Manage. 3:46-51.

Elwell, H. M., W.E. McMurphy, and P.W. Santelmann. 1970. Burning and 2,4,5-T on post and blackjack oak rangelands in Oklahoma. Oklahoma Agric. Exp. Stn. Bull. 675. Stillwater, Okla.

Engle, D.M. 1994. Cross-Timbers-Oklahoma SRM 731. In: Thomas N. Shiflet (ed.), Rangeland cover types of the United States. Society for Range Manage. Denver, Colo.

Engle, D.M., J.F. Stritzke, and F.T. McCollum. 1991. Vegetation management in the Cross Timbers: Response of understory vegetation to herbicides and burning. Weed Tech. 5:406-410.

Gay, D.L., E.R. Allen, D.M. Engle, and J.F. Stritzke. 1996. Nitrate dynamics following brush control in a post oak-blackjack oak forest. Agron. J. (in press).

Hibbert, A.R., E.A. Davis, and D.G. Scholl. 1974. Chaparral conversion in Arizona. I. Water yield and effects on other resources. USDA Forest Serv. Res. Pap. RM-126.

Johnson, F.L. and P.G. Risser. 1974. Biomass, annual net primary production, and dynamics of six mineral elements in a post oak-blackjack forest. Ecology 55:1246-1258.

Khanna, P.K. and B. Ulrich. 1991. Ecochemistry of temperate deciduous forests, p. 121-163. In: E. Röhrig and B. Ulrich (eds.) Temperate deciduous forests. Ecosystems of the world. vol. 7. Elsevier Science Publishers, Amsterdam, Publishers, Amsterdam, The Netherlands.

Klimo, E. and J. Kulhavy. 1994. Nitrogen cycling in Norway spruce stands after clear cutting. Lesnictví (Forestry) 40,(7-8):307-312.

Knight, R.W., W.H. Blackburn, and C.J. Scifres. 1983. Infiltration rates and sediment production following herbicide/fire brush treatments. J. Range Manage. 36:154-157. 
Likens, G.E., F.H. Bormann, N.M. Johnson, D.W. Fisher, and R.S. Pierce. 1970. Effects of forest cutting and herbicide treatment on nutrient budgets in the Hubbard Brook ecosystem in New Hampshire. Ecol. Monogr. 40:23-47.

Lloyd-Reilley, J., C.J. Scifres, and W.H. Blackburn. 1984. Hydrologic impacts of brush management with tebuthiuron and prescribed burning on post oak savannah watersheds, Texas. Agric. Ecosys. and Environ. $11: 213-224$.

McCollum, F.T., D.M. Engle, and J.F. Stritzke. 1987. Brush management on the Cross Timbers Experimental Range: III. Livestock gains and carrying capacity. Okla. Agr. Exp. Sta. MP-119:110-113. Stillwater, Okla.

Myers, H.R. 1982. Climatological data of Stillwater, Oklahoma 1893-1980. Okla. Agr. Exp. Sta. Res. Rep. P-321. Stillwater, Okla.

Scifres, C.J., J.W. Stuth, and B.H. Koerth. 1987. Improvement of oakdominated rangeland with tebuthiuron and prescribed burning. Texas Agr. Exp. Sta. B-1567. College Station, Tex.

Scifres, C.J., J.W. Stuth, D.R. Kirby, and R.F. Angell. 1981. Forage and livestock production following oak (Quercus spp.) control with tebuthiuron. Weed Science 29:535-539.

Sears, W.E., C.M. Britton, D.B. Wester, and R.D. Pettit. 1986. Herbicide conversion of a sand shinnery oak (Quercus havardii) community: effects on nitrogen. J. Range Manage. 39:403-407.
Smith, A.E. 1988. Potential use of tebuthiuron for site preparation in land-use conversion.. Georgia Agr. Exp. Sta. Bull. 360. Athens, Ga.

Smith, A.E., J.J. Silvoy, and L.L. Goodroad. 1987. A soil-conserving system for converting woodland to pasture. J. Soil Water Cons. 42:198-200.

Soil Conservation Service. 1981. Land resource regions and major land resource areas of the U.S. Agr. Handb. No. 296. USDA U.S. Government Printing Office, Washington D.C.

Stritzke, J.F., D.M. Engle, ard F,T. McCollum. 1991. Vegetation management in the Cross Timbers: Response of woody species to herbicides and burning. Weed Tech. 5:400-405.

Van Lear, D.H. and P.R. Kapeluck. 1989. Fell and burn to regenerate mixed pine-hardwood stands: an overview of effects on soil. In: T.A. Waldrop (ed.) Proceedings of pine-hardwood mixtures: A symposium on management and ecology of the type. USDA For. Ser. Gen. Tech. Rep. SE-58. Asheville, N.C.

Vitousek, P.M. 1981. Clear-cutting and the nitrogen cycle. In: Clark, F.E. and Rosswall, T. (eds.), Terrestrial Nitrogen Cycles. Processes, Ecosystem Strategies and Management Impacts. Ecol. Bull. (Stockholm) 33:631-642.

Vitousek, P.M. and J.M. Melillo. 1979. Nitrate losses from disturbed forests: patterns and mechanisms. Forest Sci. 25:605-619.

Waller, S.S. and J.K. Lewis. 1979. Occurrence of C3 and C4 photosynthetic pathways in North American grasses. J. Range Manage. 32:1228. 